\title{
Ecological and biological studies in the haplic chernozems pacnic soils area in the Central Caucasus (Kabardino-Balkaria)
}

\section{Tatyana Uligova, Olga Gorobtsova, Nelli Tsepkova, Irina Rapoport, Fatima Gedgafova, and Rustam Tembotov}

Federal State Budget Scientific Establishment Tembotov Institute of Ecology of Mountain Territories, Russian Academy of Sciences, ul. I. Armand, 37-a, Nalchik, 360051, Russian Federation

Address correspondence and requests for materials to Tatyana Uligova, ecology_lab@mail.ru

\section{Abstract}

The northern macroslope of the Central Caucasus and adjacent areas of the Middle Ciscaucasia belong to the Northeast Caucasian (semi-desert) type of vertical zonation. This type, which includes terskiy and elbrusskiy variants of vertical zonation, differs from the Northwest Caucasian vertical zonation by general xerophytization of landscapes. The Haplic Chernozems Pacnic soils of Kabardino-Balkaria formed within steppe zone of mentioned variants are almost entirely involved in agricultural use; natural ecosystems with characteristic species composition of natural vegetation and mesofauna were preserved only in small areas inconvenient for arable activity. Characteristics of the current ecological-biological state of the steppe ecosystem components from the Haplic Chernozems soils area (soil - vegetation - earthworms) is given. The values of synecological indices (Shannon's, Simpson's, Pielou's, Hartley's, and integral) characterize high floristic and phytocenosis diversity, and synantropization indices correspond to average levels. Earthworms are in abundance and represent the largest part of the mass of soil organisms in species composition, which corresponds to steppe zonal conditions and testifies to the dominance of the saprotrophic complex. The correlation and factor analysis by the principal components method shows wide ranges of interdependence in functioning of ecosystems components: between diversity of biotic communities and biological properties (humus content, microbial biomass carbon contents $\left(C_{\text {mic }}\right)$, intensity of microbial respiration, enzymatic activity) and physicochemical properties ( $\mathrm{pH}$ of soil solution, field moisture, soil density) of Haplic Chernozems.

Keywords: Central Caucasus, Haplic Chernozems Pacnic soils, steppe zone, humus, biological activity, phytocenoses, earthworms, biodiversity indices. Senior Scientist, orcid.org/0000-0003

0493-8314; Olga Gorobtsova, Ph.D., Senior Scientist, orcid.org/0000-0002-4818-7789; Nelli Tsepkova, Ph.D., Senior Scientist, orcid. org/0000-0002-6904-9705; Irina Rapoport Ph.D., Head of Laboratory, orcid.org/0000 0002-6766-1482; Fatima Gedgafova, Ph.D. Senior Scientist, orcid.org/0000-0002-19548717: Rustam Tembotov, Ph.D., Senior

Scientist, orcid.org/0000-0002-2342-4653

Manuscript Editor: Evgeny Abakumov, Saint Petersburg State University, Russia;

Received: November 03, 2017;

Revised: February 21, 2018;

Accepted: March 20, 2018;

Copyright: @ 2017 Uligova et al. This is an open-access article distributed under the terms of the License Agreement with Saint Petersburg State University, which permits to the authors an unrestricted distribution and self-archiving free of charge.

Funding: No funding information provided Competing interests: The author has declared that no competing interests exist.

\section{Introduction}

Following soil degradation and subsequent deterioration of soil biospheric and ecological functions as well as biodiversity reduction in natural ecosystems, assessment of the current state of biotic communities is a priority direction for soilecological studies (Dobrovolskiy and Nikitin, 1990; Khaziev, 2011). Monitoring of the state of steppe ecosystems of the Central Caucasus (Kabardino-Balkaria) is urgent, as they are now endangered (Tembotova and Tsepkova, 2009).

While soils and vegetation of the steppe zone in the republic are sufficiently studied (Fiapshev et al., 1985; Kerefov and Fiapshev, 1966; Shkhagapsoev, 2015; Tsepkova, 2006), there is no information on the ecological-biological characteristics of the steppe ecosystem components evolutionarily created under bioclimatic conditions of a particular variant of vertical zonation. According to the concept of biological effect of altitudinal-zonal structure of the Caucasus mountain systems (Sokolov and Tembotov, 1989), ecological-geographical peculiarities of each vari- 


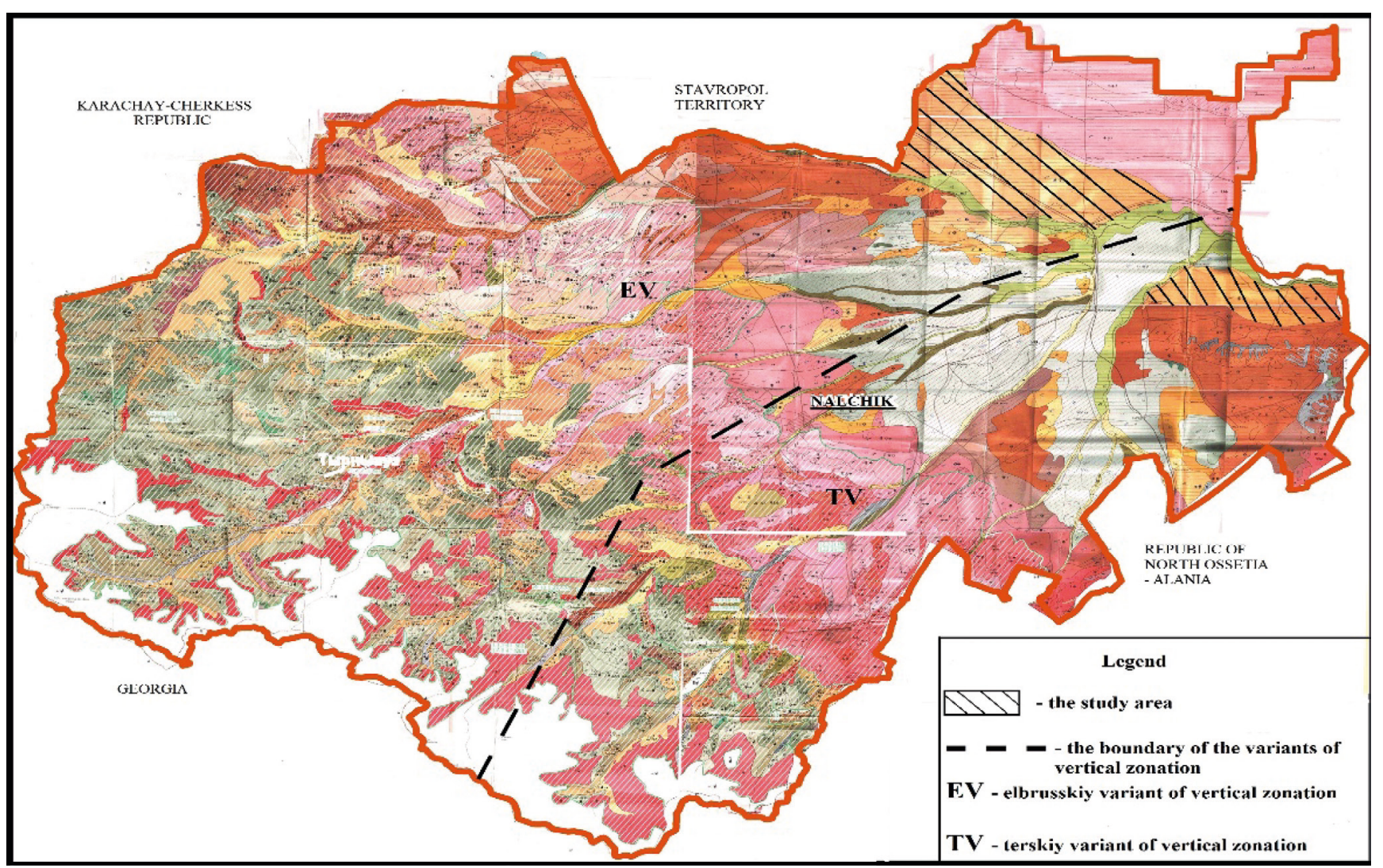

Fig. 1. The study sites location (Soil map of the Kabardino-Balkar ASSR, 1990).

ant of vertical zonation are determinative in formation of soils, vegetation and fauna (including mesofauna).

The Haplic Chernozems Pacnic soils (World Reference Base, 2006) are in the steppe zone within the terskiy and elbrusskiy variants of the Northeast Caucasian (semi-desert) type of vertical zonation (Sokolov and Tembotov, 1989), characterized by general xerophytization of landscapes. The main areas of Haplic Chernozems Pacnic soils within Kabardino-Balkaria are in agricultural use, and natural ecosystems with characteristic species composition of vegetation and soil mesofauna were preserved only in small areas. Ecological and biological studies in the area of Haplic Chernozems Pacnic soils make it possible to characterize the current state of the basic components of natural ecosystems and represent research continuation as part of developing methods to conduct ecological assessment of the soils within the Central Caucasus (Gedgafova, Uligova, Gorobtsova, and Tembotov, 2015; Gorobtsova, Khezheva, Uligova, and Tembotov, 2015).

The objective of the study is to assess ecologicalbiological characteristics of the components that are principal in the functioning of natural ecosystems (soils, plant associations, earthworms) formed in the Haplic Chernozems Pacnic soils area of the Central Caucasus (Kabardino-Balkaria).

\section{Material and methods}

\section{STUDY SITES}

The basic components of natural ecosystems in the steppe zone of Kabardino-Balkaria - Haplic Chernozems Pacnic soils, plant associations of this area, and earthworms as representatives of mesofauna - are the objects of this study. The Haplic Chernozems Pacnic soils area (total area $48,6 \times 10^{3} \mathrm{ha}$ ) is in the northeastern part of the inclined Kabardinskaya plain (180-300 m a.s.l.) within the elbrusskiy and terskiy variants of vertical zonation, and it belongs to the Ciscaucasian soil province of South-European facies (Fiapshev et al., 1985; Kerefov and Fiapshev, 1966). These soils are characterized as very warm and periodically frozen, and they comprise properties of two soil types - Haplic Kastanozems Chromic and Voronic Chernozems Pacnic soils with dominace of Chernozem type in pedogenesis (Fiapshev et al., 1985; Val'kov, Kolesnikov, and Kazeev, 2002). According to the genetic classification (Classification ..., 1977), Haplic Chernozems Pacnic soils are represented by widely spread calcaric soils (> 70\%) and calcaric residual-meadow soils.

Chernozems calcaric soils are formed in the elbrusskiy variant of vertical zonation with more homogeneous relief and xerophytization, and occupy a transition area between Voronic Chernozems Pacnic soils and Haplic 


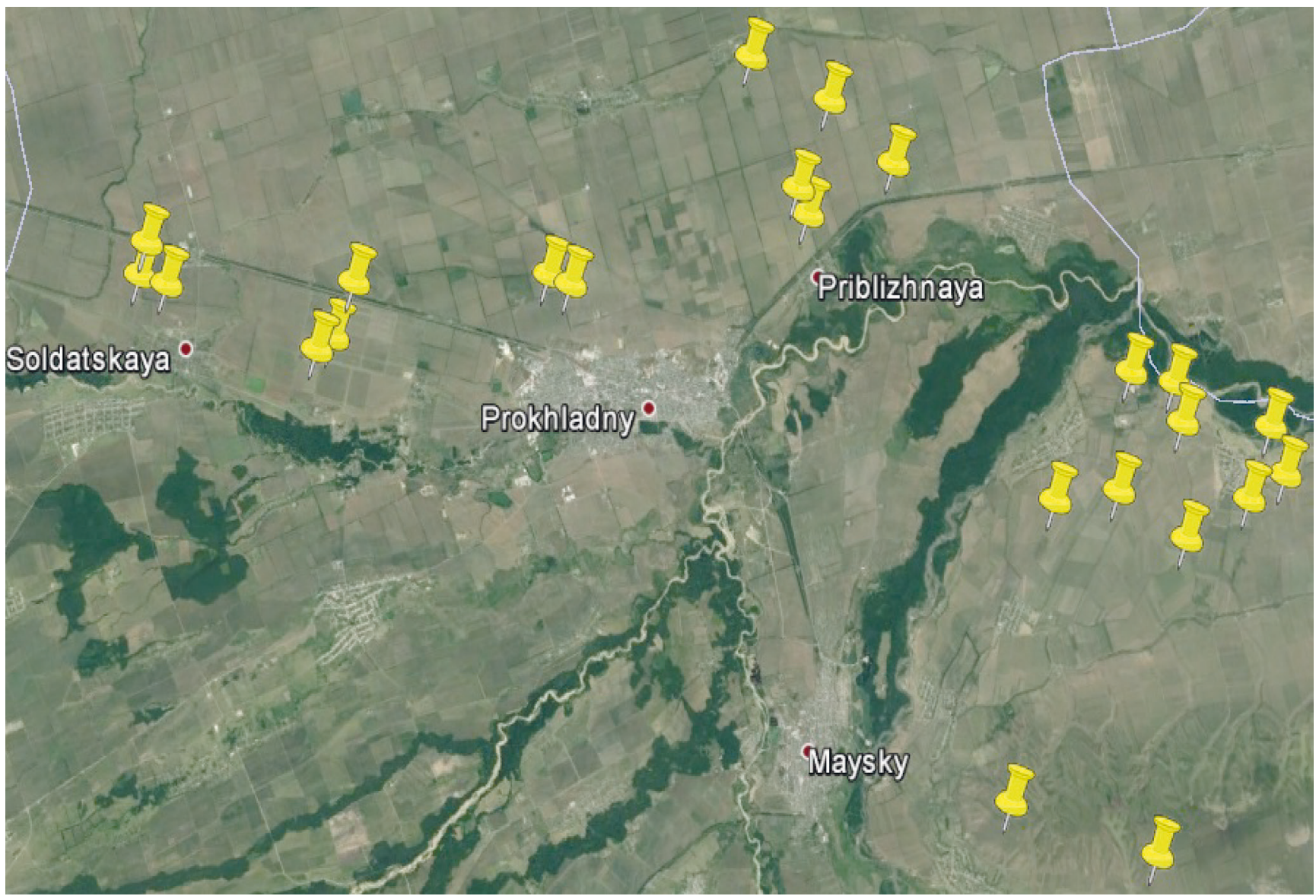

Fig. 2. The study site locations in the area of Haplic Chernozems Pacnic soils of Kabardino-Balkaria.

Kastanozems Chromic soils (Fig. 1). Chernozems calcaric residual-meadow soils embrace a rather narrow plain area between the right bank of the Terek river and northern spurs of the Terskiy range in the terskiy variant of vertical zonation, which is more geomorphologically complex.

On the one hand, the vegetation communities of Chernozems correspond to soil conditions; on the other hand, they serve to form the most important biological properties of the given soil. In natural ecosystems, motley-grass - xerophytes and xeromesophytes prevail: meadow-steppe, steppe and meadow species (Tsepkova, 2006). Earthworms dominate in the total soil fauna biomass (Rapoport, 2010), and their influence on humification processes is a well-studied and established fact (Krivolutskiy, 1994; Kvavadze, 1985; Perel, 1979).

\section{CLIMATIC CONDITIONS}

Climatic conditions of the region under survey are transitional, from mild moderate continental climate to climate of arid steppes in the Ciscaucasus. Summers are dry (hydrothermal coefficient is $0.55-0.63$ ) with frequent dry winds and winters are short and mild (average temperature of $1.0^{\circ} \mathrm{C}$ ) with short-term and weak soil freezing, which provides special conditions for vegetation and biochemical processes, since there is no hibernation in deeper strata. The sum of temperatures above $10^{\circ} \mathrm{C}$ during active vegetation is $3400-3500^{\circ} \mathrm{C}$. Annual average ambient temperature of the steppe zone in the elbrusskiy variant is $11.3^{\circ} \mathrm{C}$, and in the terskiy variant $-11.6^{\circ} \mathrm{C}$; average summer temperatures are $22.7^{\circ} \mathrm{C}$ and $22.9^{\circ} \mathrm{C}$ respectively. Average annual precipitation is $500 \mathrm{~mm}$ and $533 \mathrm{~mm}$, and in summer - $181 \mathrm{~mm}$ and $200 \mathrm{~mm}$, respectively (Ashabokov et al., 2008).

\section{METHODS OF STUDIES}

Soil and vegetation sampling was performed in field seasons at the beginning of July in 2010-2015. The coordinates were determined by cartographic data (Molchanov, Kalmakov, and Romanova, 1990) and personal navigator GPSMAP 60CEX. Sampling points were bounded by $43^{\circ} 54^{\prime} 36^{\prime \prime}-43^{\circ} 84^{\prime} 87^{\prime \prime} \mathrm{N}$, and $43^{\circ} 83^{\prime} 21^{\prime \prime}-$ $44^{\circ} 37^{\prime} 19^{\prime \prime}$ E, and within 174-266 m a.s.l. (Fig. 2). Soil samples were taken from the topsoil $(0-20 \mathrm{~cm})$ using the envelope method. Proportionally to the occupied area, the number of sampling points for Chernozems calcaric soils is 16 , and for Chernozems calcaric residual-meadow soils -7 . In profile study of morphological and 
biochemical properties, soil sampling was performed according to the genetic horizons in the environs of Terekskoe village (N 4365'748”, E 4428'732”, $175 \mathrm{~m}$ a.s.l.).

Enzymatic activity, soil respiration and species composition of soil mesofauna are widely used in current soil-ecological studies as objective and sensitive indicators of the biological state (Ananyeva, 2003; Bastida, Moreno, Hernandez, and Garcia, 2008; Dick, 1997; Khaziev, 2011; Krivolutskiy, 1994). Enzymatic activity was determined according to Galstyan (1974) by means of colorimetry (urease, phosphatase, invertase, dehydrogenase) and gasometry (catalase). Sterile soils were used as a control $\left(180^{\circ} \mathrm{C}, 3\right.$ hours). Potential intensity of soil microbial respiration was estimated by titration of alkaline solution with HCI $(0.1 \mathrm{~N})$ acid after incubation of soil samples at $30^{\circ} \mathrm{C}$ for 24 hours at optimal humidity (60\% of maximum water-holding capacity (MWHC)) (Kazeev, Kolesnikov, and Val'kov, 2003). Microbial biomass carbon content $\left(\mathrm{C}_{\text {mic }}\right)$ was determined by the substrate-induced respiration (SIR) method with the formula: $\mathrm{C}_{\mathrm{mic}}(\mathrm{mkgC} / \mathrm{g}$ soil $)=\operatorname{SIR}\left(\mathrm{mkl} \mathrm{CO}_{2} / \mathrm{g}\right.$ soil $\left./ \mathrm{h}\right) \times$ $40.04+0.37$ (Ananyeva, 2003; Anderson and Domsch, 1978). Enzymatic activity and intensity of soil microbial respiration were evaluated on Gaponyuk and Malakhov's scale (1985) and the content $\mathrm{C}_{\mathrm{mic}}$ - on the recommended scale (Ananyeva, 2003). Humus content (Corg $\times 1.724$ ) was determined with Tyurin's method modified by Nikitin (Kazeev, Kolesnikov, and Val'kov, 2003), $\mathrm{pH}$ of soil-water suspension (1:2.5) was measured by potentiometric method, and the soil moisture and density were estimated gravimetrically according to routine procedures. Analytical redefining was 3-6 fold.

Descriptions of vegetation communities were performed during field research synchronous with soil sampling by the traditional method in 11 sample plots $\left(100 \mathrm{~m}^{2}\right)$. Species abundance of phytocenoses was estimated on Braun-Blanke's scale, and similarity in species composition - by Jaccar's coefficient (Mirkin, Rozenberg, and Naumova, 1989). The share of synanthropic species was estimated according to the gradation (Abramova, 2004). To characterize diversity and sustainability of phytocenoses, synecological indices (Shannon's-, Simpson's-, Pielou's index) were calculated using the natural logarithm of the species relative projective cover. Floristic diversity was determined with Hartley's formula as the binary logarithm of the species numbers: $\mathrm{H}_{\text {flor }}=\log _{2} \mathrm{~N}$ (Popova, 2016). Biodiversity indices were unified into a general integral index (Andreev, 2002).

Earthworm samples were collected from soil monoliths $25 \times 25 \mathrm{~cm}^{2}$ using Gilyarov's method (1975), and species rank was determined using Vsevolodova-Perel's method (1997).

Statistical processing included a t-test for independent samples ( $t$-test, independent by groups), correlation analysis (correlation matrices), and factor analysis by the principal components method (PCA). We used the level of significance $\alpha \leq 0.05$ (Puzachenko, 2004).

\section{Results and discussion}

\section{VEGETATION COVER}

Natural vegetation forming a complex of ecological-biological properties in Haplic Chernozems Pacnic soils is represented by gramineous, motley grasses-gramineous, and fabaceous-motley grasses-gramineous phytocenoses (Table 1). Bothriochloa ischaemum, Poa angustifolia, Cynodon dactylon, Bromus mollis, and Elytrigia repens are registered as dominants and subdominants. In some motley grass associations Artemisia annua, Xeranthemum cylindraceum and Consolida paniculata are dominant including synantropic species - Erigeron canadensis and Centaurea diffusa. General projective grass cover comprises $65 \%-100 \%$; average height of grass stand is $25-50 \mathrm{~cm}$. Phytocenoses are formed by $83 \mathrm{spe}-$ cies; among them motley grasses constitute $66 \%$, gramineous grasses and legume grasses have equal proportions $-17 \%$.

The number of species Anisantha sterilis, Setaria viridis, Phleum nodosum, Carthamus lanatus, Daucus carota, Asperula humifusa, Sisymbrium loeselii, Plantago media and some others is insignificant. Salvia aethiopis, Chamomilla recutita, Sorghum halepense, Astrodaucus orientalis, Linum austriacum, Glycyrrhyza glabra, Inula aspera and Tragopogon dubius are of isolate occurrence.

In the cenosis spectrum the steppe species (S) (30\%) and synantropic species (SA) (42\%) are dominant. The number of meadow-steppe species $(\mathrm{M}-\mathrm{S})$ is limited to $20 \%$, and of meadow species $(\mathrm{M})-$ to $9 \%$. The share of synanthropic species (SA) in communities corresponds to average level of synantropisation (31-50\%) (Abramova, 2004). In the ecological spectrum xeromesophytes (X M) (37\%) and xerophytes (X) (28\%) prevail; mesophytes (M) (19\%) and mesoxerophytes (M X) (16\%) are dependent.

According to Jakkar's method, similarity in the species composition between the studied phytocenoses in both elbrusskiy and terskiy variants of vertical zonation doesn't exceed 13\%, and only in some points (between some phytocenoses in the terskiy variant in the Pacnic Chernozems calcaric residual-meadow soils area) it comprises 20-29\%. Synecological and integral indices characterize diversity and balance of associations. As follows from Fig. 3A, the indices of floristic diversity (calculated with Hartley's formula) vary within 3.17-4.64. The values of Shannon's index (the range is 2.01-2.95) are close to maximum possible (2.30-3.22) (Andreev, 2002 ) in the associations under survey; the number of species is variable from 9 to 25 . This proves high diversity and characterizes the degree of formation and stability in the phytocenoses. 
Table 1. List of common species of plants and their ecological characteristics in natural phytocenoses in the Haplic Chernozems Pacnic soils area of Kabardino-Balkaria

\begin{tabular}{|c|c|c|c|c|c|}
\hline Plants & $\begin{array}{l}\text { Ecological } \\
\text { group }\end{array}$ & $\begin{array}{l}\text { Cenosis } \\
\text { groups }\end{array}$ & Plants & $\begin{array}{l}\text { Ecological } \\
\text { group }\end{array}$ & $\begin{array}{l}\text { Cenosis } \\
\text { groups }\end{array}$ \\
\hline \multicolumn{3}{|l|}{ Fam. Poaceae } & \multicolumn{3}{|l|}{ Motley grass species } \\
\hline Bothriochloa ischaemum & $x$ & $S$ & Artemisia vulgaris & M & SA \\
\hline Bromus mollis & XM & $\mathrm{M}-\mathrm{S}$ & Centaurea diffusa & $x$ & SA \\
\hline Cynodon dactylon & $\mathrm{MX}$ & $s$ & Centaurea iberica & $x$ & SA \\
\hline Elytrigia repens & XM & $M ; M-S$ & Cichorium intybus & XM & SA \\
\hline Hordeum leporinum & XM & SA & Cirsium arvense & XM & SA \\
\hline Poa angustifolia & $\mathrm{MX}$ & $s$ & Convolvulus arvensis & $M X$ & SA \\
\hline \multicolumn{3}{|l|}{ Fam. Fabaceae } & Consolida paniculata & XM & S; SA \\
\hline Coronilla varia & M & M & Echium vulgare & XM & SA \\
\hline Lotus corniculatus & XM & $M-S$ & Erigeron canadensis & $x$ & SA \\
\hline Medicago Iupulina & $\mathrm{MX}$ & SA & Eryngium campestre & $x$ & SA \\
\hline Thymus marschallianus & $\mathrm{MX}$ & $S$ & Inula germanica & $x$ & $S$ \\
\hline Trifolium arvense & $M X$ & $s$ & Leonurus quinquelobatus & XM & SA \\
\hline Trifolium pratense & M & M & Nigella arvensis & $\mathrm{MX}$ & S; SA \\
\hline Trifolium repens & M & M; SA & Phalacroloma annuum & XM & SA \\
\hline \multicolumn{3}{|l|}{ Motley grass species } & Plantago lanceolata & XM & S; SA \\
\hline Alcea rugosa & XM & $\mathrm{M}-\mathrm{S}$ & Plantago media & M & SA \\
\hline Achillea millefolium & $\mathrm{MX}$ & $M-S$ & Potentilla argentea & $x$ & S \\
\hline Agrimonia eupatoria & XM & $M-S$ & Prunus spinosa & $x$ & $S$ \\
\hline Ambrosia artemisiifolia & M & SA & Salvia verticillata & $\mathrm{MX}$ & $M-S$ \\
\hline Artemisia annua & XM & SA & Senecio vulgaris & XM & SA \\
\hline Artemisia austriaca & $x$ & S; SA & Taraxacum officinale & $M$ & SA \\
\hline Artemisia taurica & $x$ & S & Xeranthemum annuum & $x$ & $S$ \\
\hline
\end{tabular}

Note: Ecological groups: $\mathrm{X}$ - xerophytes, $\mathrm{M} \mathrm{X}$ - mesoxerophytes, $\mathrm{X} \mathrm{M}$ - xeromesophytes, $\mathrm{M}$ - mesophytes. Cenosis groups: $\mathrm{S}$ - steppe, $\mathrm{M}$ - meadow, $\mathrm{M}-\mathrm{S}$ - meadow-steppe, SA — synantropic.

The values of Simpson's (0.06-0.18) and Pielou's indices $(0.83-0.92)$ are responsive to changes in the dominance structure and testify to equal presence of the species to form steppe phytocenoses (Fig. 3A). Coefficients of variation $\left(\mathrm{C}_{\mathrm{v}}=3.51-11.8 \%\right)$ of Shannon's-, Pielou's-, and Hartley's indices reflect similarity of ecological conditions for phytocenoses of the Haplic Chernozems Pacnic soils area. The conclusion is supported by close values $\left(\mathrm{C}_{\mathrm{v}}=4.9 \%\right)$ of calculated integral indices (Fig. 3B), which combine all the determined diversity indices in the associations under survey.

\section{EARTHWORMS}

Earthworms were taken to characterize the biological state of Haplic Chernozems Pacnic soils, as their abundance and species composition have great impact on formation of soil properties (Edwards and Bohlen, 1996; Krivolutskiy, 1994; Perel, 1979; Striganova, 1999).

Compared to forest soils, steppe soils, and specifically arid Haplic Chernozems Pacnic soils, differ by reduction of absolute and relative earthworm abundance in upper soil horizons. Earthworms fam. Lumbricidae dominate in the humus profile of given Chernozems within Kabardino-Balkaria. The species composition of earthworms corresponds to steppe zonal conditions four species of Lumbricidae are registered in plakor conditions within the area of Chernozems. Apporrectodea rosea (Savigny, 1826) and A.caliginosa trapezoides (Dugès, 1828) are dominant in most ecosystems; Dendrobaena mariupolienis mariupolienis Wyssotzky, 1898 is of frequent occurrence; D.tellermanica Perel, 1966 is registered in the beardgrass-quackgrass steppe. 


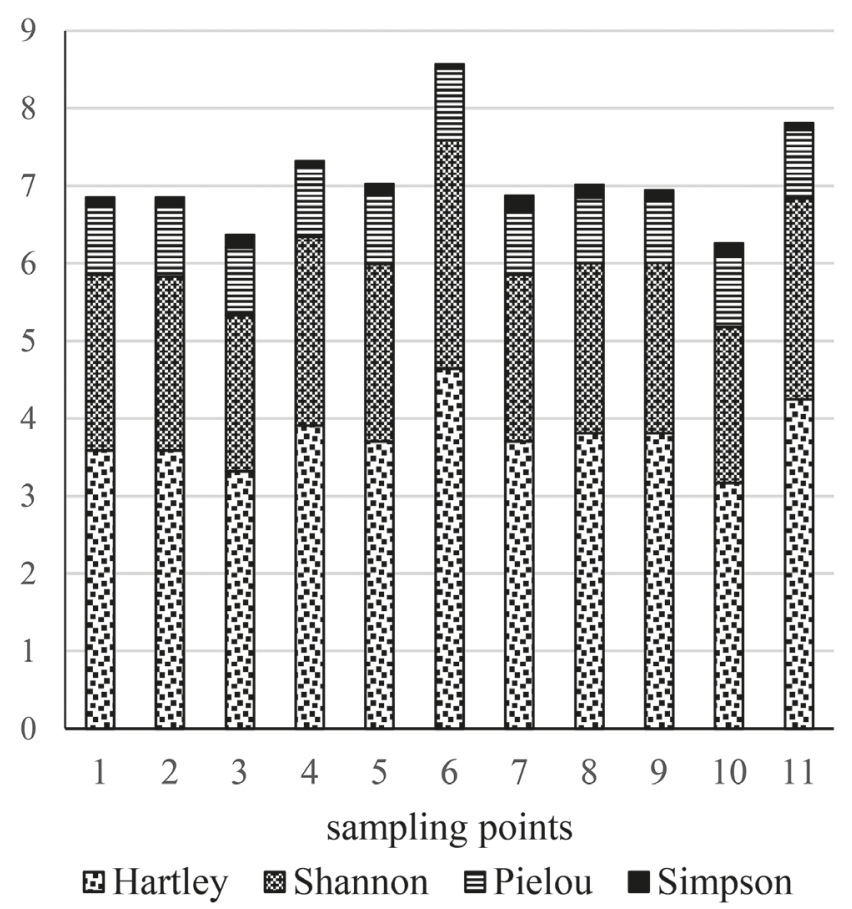

A

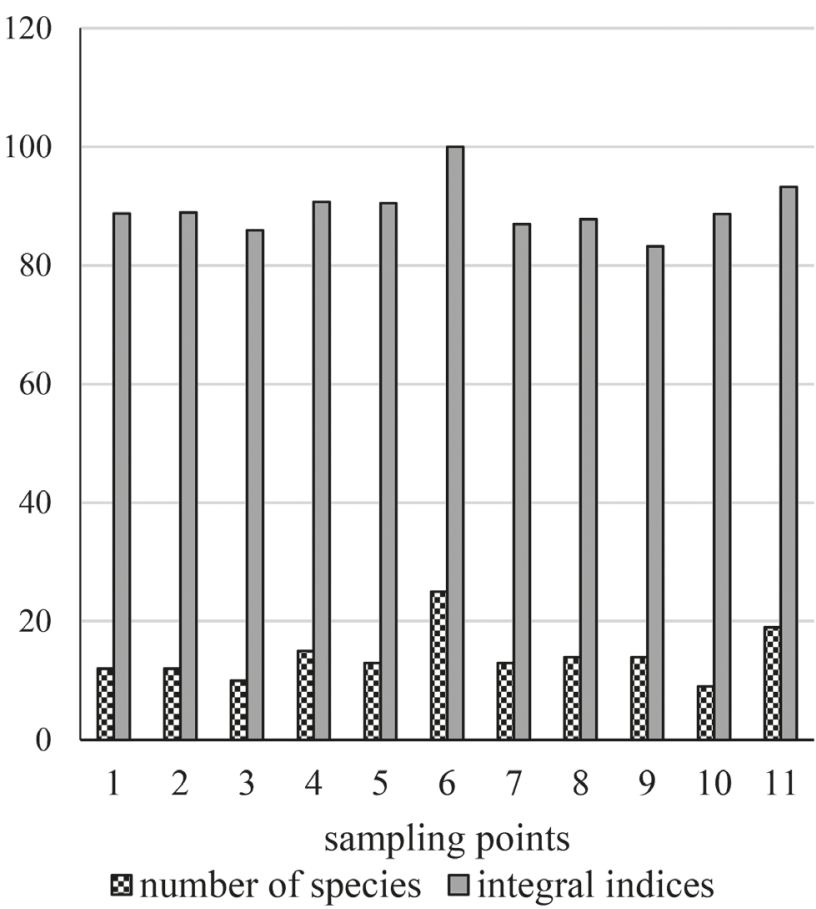

B

Fig. 3. A - synecological indices; B - integral indices (\%) and species number in phytocenoses of Haplic Chernozems Pacnic soils area in Kabardino-Balkaria.

As the temperature of the A1-horizon varies from $25.7^{\circ}$ to $26.4^{\circ} \mathrm{C}$, diapause is evident in almost all samples, and juvenile worms prevail in tests. Distribution is determined by microrelief peculiarities and has a local character: in some tests $\left(25 \times 25 \mathrm{~cm}^{2}\right)$ the population density of A.caliginosa trapezoides comprises 8-11 specimens/ $\mathrm{m}^{2}$, and of $A$. rosea -21 specimens $/ \mathrm{m}^{2}$; some tests are empty. Consequently, the average total earthworm numbers range from 3 to 180 specimens $/ \mathrm{m}^{2}$; biomass is $0.64-$ $24.7 \mathrm{~g} / \mathrm{m}^{2}$. Lumbricidae representatives are registered at the depth of $20-35 \mathrm{~cm}$, and they account for $21-51 \%$ of the total mesofauna numbers. This testifies to the dominance of the saprotrophic complex in the species composition of Haplic Chernozems Pacnic soils, and it also corresponds to the data on the above-mentioned soils from the steppe ecosystems of European Russia, obtained by Striganova (2005).

All the species identified in Haplic Chernozems Pacnic soils show a complex of morphophysiological adaptations and are well adapted to cold winters and dry vegetation periods with hot summers (Perel, 1979). D. mariupolienis mariupolienis is a night crawler that makes vertical burrows to the depth of $8 \mathrm{~m}$ (Visotskiy, 1962). D. mariupolienis mariupolienis also has the ability to undergo diapause. According to Prokonova's data (2006), $46 \%$ of specimens of D. mariupolienis mariupolienis go into an inactive state in 10 days when water capacity is reduced to $23 \%$ of its maximum. D.mari- upolienis mariupolienis is characterized by optimum survival rate during the experiment. A. rosea and D.tellermanica are endogeic earthworms which migrate into deeper mineral soil layers and go into diapause under drought conditions. In A.rosea the total diapause lasts 8-10 months (Kvavadze, 1985; Rapoport, 2010). D. tellermanica is similar in ecology to A.rosea and is found in the same habitats of the North Caucasus; however, its diapause occurs at a shallower depth and for a shorter duration. Some authors consider A.caliginosa trapezoides an ecotype or "intermediate" form between endogeic and epigeic earthworms feeding in the topsoil (Abukenova and Khunturin, 2010; Fernández et al., 2010). In the Caucasus A.caliginosa trapezoides is often found in the steppe zone, and in its plakor habitats it goes into diapause in May (Rapoport, 2010).

Thus, in summer the majority of zoomass, which is mostly contributed by earthworms, is concentrated in deeper horizons. In spite of the severe hydrothermal regime in the area of studied Chernozems, the numbers of earthworms is significant. Distribution has a mosaic character and is determined by microrelief peculiarities. All the species found in Haplic Chernozems Pacnic soils refer to the steppe complex of Lumbricidae and are well adapted to the amplitude of seasonal temperature and humidity peculiar to steppe habitats. Significant numbers of endogeic earthworms and frequent occurrence of anecic D. mariupolienis mariupolienis testify to a high 


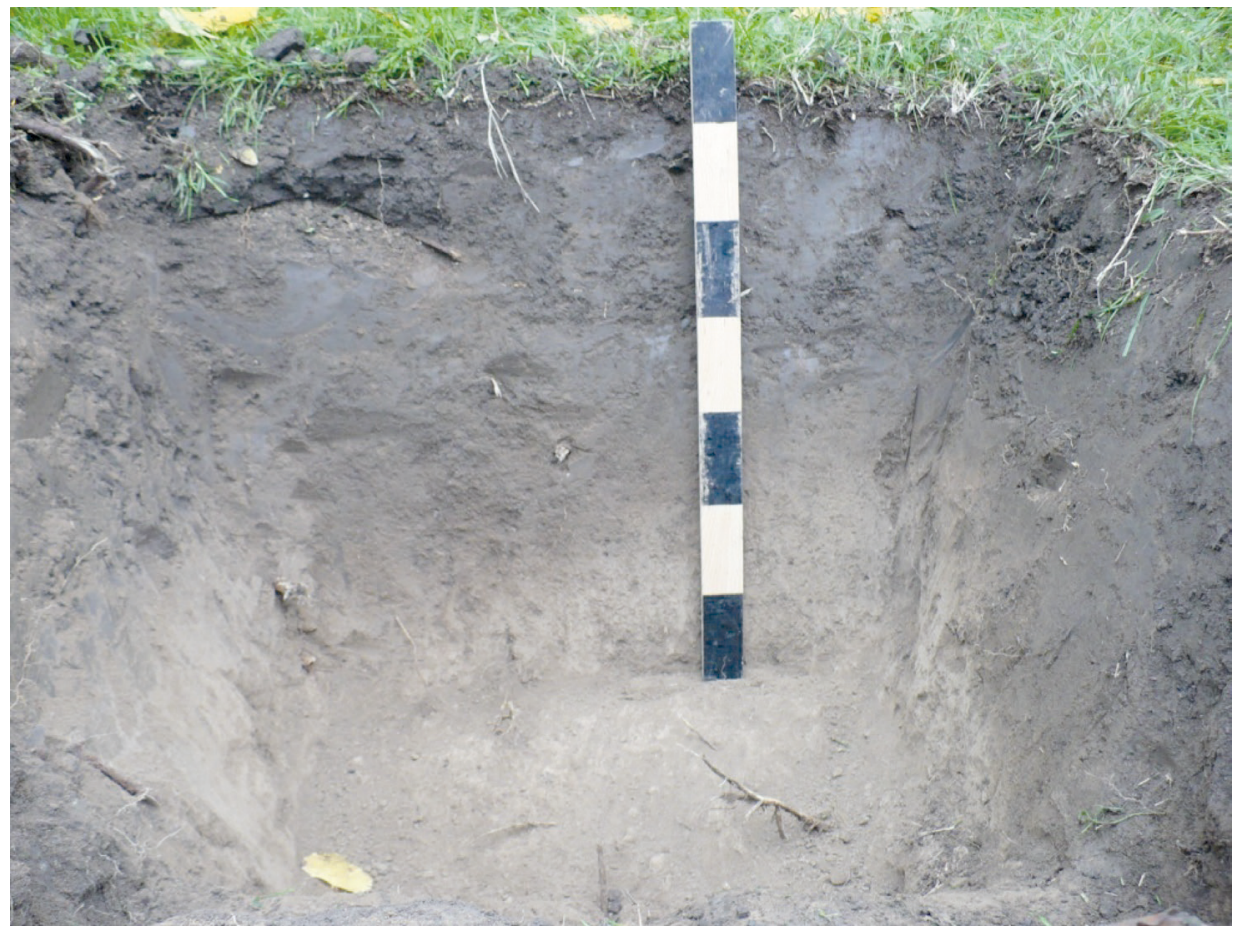

Fig. 4. The profile of Haplic Chernozems Pacnic calcaric residual-meadow soil. Environs of Terekskoe village, Kabardino-Balkaria.

rate of decomposition and plant mass mineralization over a relatively short period of Lumbricidae activity, which coincides with spring and autumn precipitations.

Biological properties of Haplic Chernozems Pacnic soils. Peculiarities of biological activity in Haplic Chernozems Pacnic soils are connected with essential soil forming factors - diversity of phytocenoses and mesofauna. As compared to other subtypes of Chernozems, Haplic Chernozems Pacnic soils are characterized by decay of sod process, less intensive humus accumulation, low content and reserves of humus (Fiapshev et al., 1985; Kazeev, Kolesnikov, and Val'kov, 2004).

The dynamic of the biochemical processes intensity can be shown on the example of the Haplic Chernozems Pacnic calcaric residual-meadow soil profile $(\mathrm{A} 1+\mathrm{A} 1 \mathrm{~B} 1=50 \mathrm{~cm})$, found under short grass steppe vegetation in the environs of Terekskoe village. The structure of the profile represents typical morphogenetic features of the Haplic Chernozems Pacnic soils (Fig. 4).

The humus horizon A1 is dark gray with a brown tint, indicating low humus content, and gradually becomes brownish. The upper horizons are penetrated by roots of herbaceous plants, and there are earthworm tunnels, or coprolites. Soil texture is heavy loamy throughout the profile; in the lower horizons the lumpy-granular structure turns into a large-lumpy-cloddy structure. The rapid boil is observed from the surface, and in the horizon $\mathrm{B} 1 \mathrm{ca}$ and lower profile there are accumulations of $\mathrm{CaCO}_{3}$ in the form of veins and carbonate mould.
The slightly alkaline reaction ( $\mathrm{pH}$ of $7.92-8.22$ ) of the soil solution gradually increases down the profile. The humus content in the horizon A1 is $3.8 \%$; it gradually decreases in lower layers, but in the horizon of $\mathrm{BCca}$ is $0.9 \%$, which testifies to the extended biochemical profile, so the humus reserve ( $300 \mathrm{t} / \mathrm{ha})$ in the meter layer of soil corresponds to the average level (Val'kov et al., 2004).

In Table 2 the profile dynamic activity of hydrolytic (urease, phosphatase, invertase) and redox (catalase, dehydrogenase) enzymes is given. The maximum biochemical activity is observed in the upper layer $0-20 \mathrm{~cm}$, which shows $64 \%$ of total enzymatic activity of the soil profile. According to the estimation scale (Gaponyuk and Malakhov, 1985), in the most biogenic horizon, A1, the Haplic Chernozems Pacnic soils have high urease activity, average catalase activity, weak phosphatase and dehydrogenase activity, and very weak invertase activity.

A decrease in activity of the studied enzymes down the profile is closely correlated with humus content and increased alkalinity of the soil solution (respectively $r=$ $0.96-0.99$ and $r=-0.87-0.96$ ). In the horizon B1ca, hydrolytic enzyme activity is reduced by $4-5$ times; redox enzymes - 1.5-2.5 times. At the depth of $80 \mathrm{~cm}$ invertase and phosphatase activity is not detected, and the activity of urease (very weak level) and redox (weak level) enzymes is preserved in the horizon BC.

The studies on spatial variation of physicochemical and biological properties in Haplic Chernozems Pacnic 
Table 2. The profile dynamic of biochemical properties of Haplic Chernozems Pacnic calcaric residual-meadow soil of the steppe zone of Kabardino-Balkaria (environs of Terekskoe village)

\begin{tabular}{|c|c|c|c|c|c|c|c|}
\hline $\begin{array}{l}\text { Horizon } \\
\text { (layer, cM) }\end{array}$ & $\mathrm{pH}\left(\mathrm{H}_{2} \mathrm{O}\right)$ & $\begin{array}{c}\text { Humus } \\
\text { content, } \\
\%\end{array}$ & $\begin{array}{c}\text { Invertase, mg } \\
\text { glucose/g/24 hours }\end{array}$ & $\begin{array}{l}\text { Phosphatase, } \\
\text { mg } \\
\mathrm{P}_{2} \mathrm{O}_{5} / 100 \mathrm{~g} / \text { hour }\end{array}$ & $\begin{array}{c}\text { Urease, } \mathrm{mg} \\
\mathrm{NH}_{3} / 10 \mathrm{~g} / 24 \text { hours }\end{array}$ & $\begin{array}{l}\text { Catalase, } \\
\text { ml } \mathrm{O}_{2} / \mathrm{g} / \\
\text { minute }\end{array}$ & $\begin{array}{c}\text { Dehydrogenase, } \\
\text { mg TPF } \\
/ 10 \mathrm{~g} / 24 \text { hours }\end{array}$ \\
\hline A1 0-20 & 7.92 & 3.8 & 4.6 & 12.5 & 38.0 & 7.3 & 3.8 \\
\hline A1B1 20-50 & 7.97 & 2.2 & 1.4 & 11.4 & 27.0 & 6.1 & 1.7 \\
\hline B1ca 50-70 & 8.01 & 1.9 & 0.9 & 2.7 & 9.8 & 4.8 & 1.5 \\
\hline B2са 70-90 & 8.17 & 1.1 & 0 & 0 & 2.4 & 3.8 & 1.0 \\
\hline BCса $90-100$ & 8.22 & 0.9 & 0 & 0 & 1.6 & 2.5 & 0.8 \\
\hline
\end{tabular}

soils were carried out in the upper layer, 0-20 cm, which shows maximum biological activity. Since the properties of calcaric and calcaric residual-meadow Chernozems can be statistically distinguished by no studied parameters $(t<1.8$; $P>0.09)$, the data on pooled samples were analyzed. Mean values and coefficients of variation are given in Table 3.

Table 3. Physicochemical and biological properties in Haplic Chernozems Pacnic soils in natural ecosystems of the steppe zone in Kabardino-Balkaria

\begin{tabular}{|c|c|c|}
\hline Parameters in the layer $0-20 \mathrm{~cm}$ & $\begin{array}{c}\text { Mean value, } \\
\text { error of } \\
\text { mean } M \pm m\end{array}$ & $\begin{array}{c}\text { Coefficient } \\
\text { of variation } \\
\text { Cv, \% }\end{array}$ \\
\hline $\mathrm{pH}\left(\mathrm{H}_{2} \mathrm{O}\right)$ & $8.24 \pm 0.04$ & 2.1 \\
\hline Humus content, $\%$ & $4.2 \pm 0.2$ & 22.1 \\
\hline Humus reserves, t/ha & $106.0 \pm 12.0$ & 35.8 \\
\hline Soil density, $\mathrm{g} / \mathrm{cm}^{3}$ & $1.3 \pm 0.03$ & 7.2 \\
\hline Field moisture, $\%$ & $9.5 \pm 1.0$ & 35.5 \\
\hline $\mathrm{CO}_{2}, \mathrm{mg} / 100 \mathrm{~g} / 24$ hours & $63.7 \pm 6.4$ & 31.5 \\
\hline $\mathrm{C}_{\text {mic }}, \mathrm{mcg} \mathrm{C} / \mathrm{g}$ of the soil & $886.5 \pm 86.1$ & 32.2 \\
\hline Invertase, mg glucose/g/24 hours & $16.9 \pm 1.0$ & 24.9 \\
\hline Phosphatase, $\mathrm{mg} \mathrm{P}_{2} \mathrm{O}_{5} / 100 \mathrm{~g} /$ hour & $20.8 \pm 1.3$ & 27.1 \\
\hline Urease, $\mathrm{mg} \mathrm{NH}_{3} / 10 \mathrm{~g} / 24$ hours & $35.9 \pm 4.1$ & 46.6 \\
\hline Catalase, $\mathrm{ml} \mathrm{O}_{2} / \mathrm{g} /$ minute & $7.0 \pm 0.5$ & 33.2 \\
\hline $\begin{array}{l}\text { Dehydrogenase, mg TPF } \\
/ 10 \mathrm{~g} / 24 \text { hours }\end{array}$ & $8.1 \pm 0.5$ & 27.6 \\
\hline
\end{tabular}

Haplic Chernozems Pacnic - the "driest" soils of this type are characterized by low values of field moisture (limits 4.5-16.5\%) during field surveys. A somewhat increased density (1.2-1.4) has also been noted by other authors (Fiapshev et al., 1985). These Chernozems have a slightly alkaline reaction of the soil solution $(\mathrm{pH}$ $\left(\mathrm{H}_{2} \mathrm{O}\right)$ 7.81-8.44) due to carbonate content of the entire profile. Acid-alkaline conditions and composition density of the humus horizon with low variability $(2.1 \%$;
7.2\%) are stable features distinguishing from biological parameters that usually have high variability in different soil types. Studied Chernozems belong to the low type of humus content in the upper layer (limits 2.95-5.9\%); humus reserves in the layer $0-20 \mathrm{~cm}(50-160 \mathrm{t} / \mathrm{ha}) \mathrm{can}$ be assessed mostly as average (Val'kov et al., 2004).

The intensity of microbial respiration reflects metabolic activity of soil microbial biomass, and is a conventional parameter of biological activity determining the limits of normal soil functioning (Ananyeva, 2003; Ananyeva, Susyan, Chernova, and Wirth, 2008). The data on the intensity of $\mathrm{CO}_{2}$ emission (limits $34.3-89.1 \mathrm{mg}$ $\mathrm{CO}_{2}$ ) show weak potential respiration activity and correlate with humus content $(\mathrm{r}=0.74)$.

The microbial biomass content $\left(\mathrm{C}_{\mathrm{mic}}\right)$ is a quantitative characteristic of the living part of the organic matter; it is extremely sensitive to different impacts and is used to assess soil quality (Ananyeva, Susyan, Chernova, and Wirth, 2008; Anderson and Domsch, 1978, 2010). $\mathrm{C}_{\text {mic }}$ varies significantly (486.9-1263.6 mkg C/g soil) in different plots of studied Chernozems, and corresponds to the average level (500-1000 mkg C/g soil).

According to the accepted scale, the assessment of hydrolytic enzyme activity indicates high urease activity and average activity of phosphatase and invertase, thus characterizing their potential ability to perform the most important biochemical processes of nitrogen, phosphorus and carbohydrate metabolism in Haplic Chernozems Pacnic soils. The limits of corresponding parameters are 12.9-62.6 mg NH 3 ; 10.2-35.5 mg $\mathrm{P}_{2} \mathrm{O}_{5}$; 4.6-23.9 mg glucose. It is known that slightly alkaline conditions are optimum for urease and phosphatase activity, but not conducive to high invertase activity (Galstyan, 1974).

Catalase and dehydrogenase involved in redox processes of the organic matter mineralization show an average level of activity (corresponding limits 3.2-11.1 ml $\mathrm{O}_{2}$; 3.8-11.8 mg TPF (Triphenylformazan)). Catalase activity is largely caused by carbonate content of the entire profile in the studied Chernozems; dehydrogenase activity is closely related to microbial soil respiration 
Table 4. The results of factor analysis (principal component method) of the set data characterizing the state of ecosystems in the Haplic Chernozems Pacnic soils of Kabardino-Balkaria

\begin{tabular}{|c|c|c|c|}
\hline \multirow{2}{*}{ Variable } & \multicolumn{3}{|c|}{$\begin{array}{l}\text { Factor Loadings (Varimax normalized) (Spreadshee } \\
\text { Extraction:Principal components (Marked loadings are }>700000 \text { ) }\end{array}$} \\
\hline & Factor 1 & Factor 2 & Factor 3 \\
\hline Species number of plant & 0.714 & -0.649 & 0.260 \\
\hline General projective grass cover, $\%$ & -0.812 & 0.109 & -0.573 \\
\hline Average height of grass, $\mathrm{cM}$ & 0.229 & -0.929 & 0.288 \\
\hline Synanthropic species, \% & 0.896 & 0.425 & -0.126 \\
\hline Synanthropic species, projective cover, \% & 0.981 & -0.045 & -0.187 \\
\hline Poaceae species, \% & -0.679 & 0.725 & 0.112 \\
\hline Poaceae, projective cover, $\%$ & -0.946 & 0.060 & 0.317 \\
\hline Fabaceae species, $\%$ & -0.934 & 0.095 & 0.345 \\
\hline Fabaceae, projective cover, $\%$ & -0.651 & -0.754 & 0.085 \\
\hline Motley grass species, \% & 0.942 & -0.210 & -0.261 \\
\hline Motley grass, projective cover, $\%$ & 0.496 & 0.194 & -0.846 \\
\hline Xerophytes & 0.613 & 0.178 & -0.769 \\
\hline Mesoxerophytes & -0.096 & 0.887 & 0.450 \\
\hline Xeromesophytes & -0.611 & -0.664 & 0.429 \\
\hline Mesophytes & 0.066 & -0.037 & 0.997 \\
\hline altitude above sea level, m a.s.l. & $-0,209$ & -0.962 & 0,173 \\
\hline $\mathrm{pH}\left(\mathrm{H}_{2} \mathrm{O}\right)$ & -0.734 & -0.219 & 0.642 \\
\hline Field moisture, \% & 0.857 & -0.406 & -0.317 \\
\hline Humus content, \% & -0.340 & 0.719 & -0.605 \\
\hline Humus reserves, t/ha & -0.359 & 0.102 & 0.927 \\
\hline Soil density, g/cm³ & 0.507 & -0.452 & 0.733 \\
\hline $\mathrm{CO}_{2}, \mathrm{mg} / 100 \mathrm{~g} / 24$ hours & 0.039 & 0.758 & -0.650 \\
\hline $\mathrm{C}_{\text {mic }}, \mathrm{mcg} \mathrm{C} / \mathrm{g}$ of the soil & -0.214 & 0.975 & -0.052 \\
\hline Invertase, mg glucose/1g/24 hours & 0.365 & 0.609 & -0.703 \\
\hline Phosphatase, $\mathrm{mg} \mathrm{P}_{2} \mathrm{O}_{5} / 100 \mathrm{~g} / 1$ hour & 0.528 & -0.640 & -0.557 \\
\hline Urease, $\mathrm{mg} \mathrm{NH} 3 / 10 \mathrm{~g} / 24$ hours & 0.193 & 0.512 & -0.836 \\
\hline Catalase, $\mathrm{ml} \mathrm{O}_{2} / 1 \mathrm{~g} / 1$ minute & -0.335 & 0.887 & -0.316 \\
\hline Dehydrogenase, mg TPF /10g/24 hours & -0.342 & -0.915 & 0.210 \\
\hline Species number of earthworms & 0.856 & 0.471 & -0.211 \\
\hline Biomass of earthworms, $\mathrm{g} / \mathrm{m}^{2}$ & 0.889 & 0.098 & -0.462 \\
\hline Abundance of earthworms, specimens $/ \mathrm{m}^{2}$ & 0.915 & -0.075 & 0.395 \\
\hline Share of earthworms in common number of mesofauna, \% & 0.938 & -0.296 & 0.180 \\
\hline Expl. Var. & 13.307 & 10.329 & 8.363 \\
\hline Prp. Totl. & 0.416 & 0.322 & 0.261 \\
\hline
\end{tabular}


$(\mathrm{r}=0.71)$ and is determined by metabolic activity of the soil microflora (Galstyan, 1974; Kazeev, Kolesnikov, and Val'kov, 2004).

As follows from Table 3, parameters of the studied biological properties in Haplic Chernozems Pacnic soils - humus content, $\mathrm{C}_{\mathrm{mic}}$, enzymatic activity, intensity of microbial respiration - are characterized by high variability $\left(C_{v} \geq 20 \%\right)$, which has also been noted by other authors (Ananyeva, 2003; Khaziev, 1982). Evidently, for Chernozems calcaric and Chernozems calcaric residual-meadow soils in variants with different orography and climatic conditions, the location affects the spatial variation level of biological properties. It should be noted that, as estimated by the complex of studied biological parameters, Haplic Chernozems Pacnic soils show lower values in intensity of biological processes than other Chernozem subtypes in the steppe zone of Kabardino-Balkaria (Gedgafova, Uligova, Gorobtsova, and Tembotov, 2015; Gorobtsova, Khezheva, Uligova, and Tembotov, 2015).

When comparing biological activity of given Chernozems under phytocenoses with different dominant species such as Poa angustifolia, Elytrigia repens, Cynodon dactylon, Erigeron Canadensis and Artemisia annua, sharp distinctions are not found. It is known that different plants affect each other through the root system homogenizing soil properties (Onipchenko, 2011). Similar results are obtained for the other plots of Chernozems, regardless of phytocenosis affiliation to the elbrusskiy or terskiy variant of vertical zonation.

The factor analysis by the principal components method of 32 characteristics from the studied ecosystems shows that field moisture, species abundance, and participation of taxonomic and ecological groups in phytocenosis formation, as well as species composition and abundance of earthworms, contribute significantly $(46 \%)$ to the variance of indices (Table 4, Factor 1). The decisive role of these factors in forming the complex of soil biological properties also has been noted by other authors (Dobrovolskiy and Nikitin, 1990; Edwards and Bohlen, 1996; Karpachevskiy, 2005; Nannipieri, Grego, and Ceccanti, 1990; Nannipieri, Kandeler, and Ruggiero, 2002).

Indicators of soil biological activity - humus content and $\mathrm{C}_{\text {mic }}$, intensity of microbial respiration and enzymatic activity - comprise the second largest contribution $(38 \%)$ to the variance of indices (Table 4, Factor 2). The least important factors (15.5\%) influencing the dispersion characteristics include the $\mathrm{pH}\left(\mathrm{H}_{2} \mathrm{O}\right)$ soil reaction, soil density and humus reserves (Table 4, Factor 3 ).

The results of correlation analysis testify to the fact that most parameters of floristic and phytocenosis diversity and earthworm species diversity are in close correlation $(\mathrm{r}=0.5-0.98)$ with soil $\mathrm{pH}\left(\mathrm{H}_{2} \mathrm{O}\right)$ and field moisture. The degree of connection (both positive and nega- tive) of the data on diversity of biotic associations and biological properties of Haplic Chernozems Pacnic soils, herewith, varies in wide ranges $(r=0.01-0.99)$, thus reflecting complex interdependence between ecosystem components in their functioning. Special consideration must be given to sustainable positive correlation $(\mathrm{r}=$ $0.40-0.90$ ) of the following parameters: humus content with general projective grass cover and poaceae projective cover $(r=0.7)$; biotic association diversity with activity of hydrolitic enzymes (urease, phosphatase and invertase) which "catalyze" vital biochemical processes of nitrogen, phosphorus and carbohydrate metabolism, and saturate soil with nutrients available to plants and microorganisms. The data obtained confirm the important role of enzymes in functional connections between ecosystem components (Caldwell, 2005; Khaziev, 2011; Nannipieri, Kandeler, and Ruggiero, 2002; Speir and Ross, 2002).

\section{Conclusion}

The ecological-biological characteristics of the steppe ecosystem components (soil, vegetation, mesofauna) from the Haplic Chernozems Pacnic soils area of Kabardino-Balkaria were assessed with special reference to local specificity of pedoenvironments. Haplic Chernozems Pacnic soils of the steppe zone within the terskiy and elbrusskiy variants of vertical zonation reflect features of xerophytization in steppe landscapes of the Northeast Caucasian (semi-desert) type. The research data on biological (humus content, $\mathrm{C}_{\mathrm{mic}}$, intensity of microbial respiration, enzymatic activity) and physicochemical properties $\left(\mathrm{pH}\left(\mathrm{H}_{2} \mathrm{O}\right)\right.$ soil solution, field moisture, soil density), along with their profile and spatial variation, characterize the current state of Haplic Chernozems Pacnic soils.

The conditions of limited atmospheric precipitation in the steppe zone, which restrain vegetation biological productivity and mesofauna activity, affect their ecological peculiarities. Xerophytes and xeromesophytes of the steppe type (30\%) prevail over meadow-steppe species (20\%) and meadow species (9\%) in the rare vegetation cover with average height of grass stand. The values of synecological indices testify to equal presence of the species to form steppe phytocenoses, high floristic and phytocenosis diversity, and prove the degree of their formation and stability; synantropization indices correspond to average level. The earthworm fauna comprises the majority of soil zoomass, and is represented by the species well adapted to the unfavourable hydrothermal regime of arid southern steppes. The results of factor and correlation analysis reflect the decisive role of biotic associations in forming the complex of biological properties of Haplic Chernozems Pacnic soils; the above-mentioned results also testify to variety of inter- 
action and interdependence in functioning of ecosystem components.

The data on the present state of natural ecosystems from the Haplic Chernozems Pacnic soils area can serve as the basis for monitoring the soil and vegetation cover in the Central Caucasus, thus making it possible to determine the trend and rate of the processes that cause changes and probable extinction of the steppe cenoses.

\section{References}

Abramova, L. M. 2004. Synantropization vegetation: patterns and control to the process (on the example of Republic Bashkortostan). Abstract of the Doctor of Science Dissertation. Perm. 45 pp.

Abukenova, V. S. and Khanturin, M. R. 2010. Adaptive features of life forms in Aporrectodea caliginosa: (Oligochaeta: Lumbricidae). Zoology in the Middle East 2:59-65.

Ananyeva, N. D. 2003. Microbiological aspects of self-purification and stability of soils. Moscow: Nauka Publishers. 223 pp.

Ananyeva, N.D., Susyan, E.A., Chernova, O. V., and Wirth, S. 2008. Microbial respiration activities of soils from different climatic regions of European Russia. European Journal of Soil Biology 44(2):147-157.

Anderson, J.P.E., and Domsch, K. H.1978. A phisiological method for the quantitative measurement of microbial biomass in soils. Soil Biology and Biochemistry 10(3):215-221.

Anderson, T.H, and Domsch, K. H. 2010. Soil microbial biomass: the eco-physiological approach. Soil Biology and Biochemistry 42(12):2039-2043.

Andreev, A. V. 2002. Assessment of biodiversity, monitoring and econets. Kishinev: BIOTICA. 167 pp.

Ashabokov, B.A., Bischokov, R. M., Zherukov, B. Kh., and Kalov, Kh.M. 2008. Analysis and forecast of climate changes of atmospheric precipitation and temperature regime in different climate belts of the North Caucasus. Nalchik. 182 pp.

Bastida, F., Moreno, J. L. A., Hernandez, T., and Garcia, C. 2008. Past, present and future of soil quality indices: a biological perspective. Geoderma 147:159-171.

Caldwell, B. A. 2005. Enzymes as a component of soil biodiversity. Pedobiologia 49:637-644.

Classification and diagnostics of soils of the USSR. 1977. Moscow: Kolos. 224 pp.

Dobrovolskiy, G. V., and Nikitin, E. D. 1990. Soil functions in biosphere and ecosystems (Ecological significance of soils). Moscow: Nauka. 261 pp.

Dick, R. P. 1997. Soil enzyme activities as integrative indicators of soil health; pp. 121-156 in Pankhurst, C., Doube, B. M. and Gupta, V.V.S.R., eds. Biological indicators of soil health. (CAB International: Wallingford, UK).

Edwards, C. A., and Bohlen, P. J. 1996. Biology and Ecology of Earthworms. London: Chapman and Hall. 426 pp.

Fernández, R., Novo, M., Gutiérrez, M., Almodóvar, A., and Díaz Cosín D. 2010. Life cycle and reproductive traits in Aporrectodea trapezoides (Dugès, 1828) (Oligochaeta, Lumbricidae) in laboratory cultures. Pedobiologia 53:295-299.

Fiapshev, B. Kh., Trofimenko, K. I., Kumakhov, V. I., Kuprichenkov, M.T., Petrov, L. N., Pishuga, N.S., and Sikorskiy, M. I. 1985. Chernozem soils of the Central and Eastern Cis-Caucasus; pp. 54-146 in Chernozems of the USSR (Cis-Caucasus and Caucasus). Moscow: Agropromizdat.

Galstyan, A. Sh. 1974. Enzymatic activity of soils in Armenia. Yerevan: Aiastan. 275 pp.
Gaponyuk, E. I., and Malakhov, S. V. 1985. Complex system of indicators of soil ecological monitoring; pp. 3-10 in Proceedings of 4th All-Union Conference. Obninsk.

Gedgafova, F. V., Uligova, T. S., Gorobtsova, O. N., and Tembotov, R. Kh. 2015. The biological activity of chernozems in the Central Caucasus Mountains (Terskiy variant of altitudinal zonality), Kabardino-Balkaria. Eurasian Soil Sciences 12:1341-1348.

Gilyarov, M. S. 1975. Consideration of large soil invertebrates (mesofauna); pp. 12-29 in Methods of soil-zoological studies. Moscow: Nauka.

Gorobtsova, O. N., Khezheva, F. V., Uligova, T. S., and Tembotov, R. Kh. 2015. Ecological and geographical regularities of changes in the biological activity of automorphic soils on the foothills and adjacent plains the Central Caucasus Region (Kabardino-Balkarian Republic). Eurasian Soil Sciences 3:303-313.

Karpachevskiy, L. O.2005. Ecological soil science. Moscow: GEOS. 334 pp.

Kazeev, K. Sh., Kolesnikov, S. I., and Val'kov, V. F. 2003. Biological diagnostics and indication of soils: methodology and methods of analysis. Rostov-on-Don: Rostov State University Press. 204 pp.

Kazeev, K. Sh., Kolesnikov, S. I., and Val'kov, V. F. 2004. Biology of soils of Southern Russia. Rostov-on-Don: Center of Valeology of Russian Higher Education Institutions. 350 pp.

Kerefov, K. N., and Fiapshev, B. Kh. 1966. Soils of the steppe zone in Kabardino-Balkarian ASSR. Nalchik: KabardinoBalkar Publishig House. 100 pp.

Khaziev, F. Kh. 1982. Systematic-ecological analysis of enzymatic activity of soils. Moscow: Nauka. 203 pp.

Khaziev, F. Kh. 2011. Soil and biodiversity. Russian Journal of Ecology 42(3):199-204.

Krivolutskiy, D. A. 1994. Mesofauna under ecological monitoring. Moscow: Nauka. 269 pp.

Kvavadze, E. Sh. 1985. The earthworms (Lumbricidae) of the Caucasus. Tbilisi: Metsniereba. 237 pp.

Mirkin, B. M., Rozenberg, G. S., and Naumova, L. G. 1989. Dictionary of definitions and terms of current phytocenology. Moscow: Nauka. 223 pp.

Molchanov, E. N., Kalmakov, V. D., and Romanova, A. K. 1990. Soil map of Kabardino-Balkar ASSR. Moscow: GUGK USSR.

Nannipieri, P., Grego, S. and Ceccanti, B. (1990) Ecological significance of the biological activity in soil; pp. 293-355 in: Bollag, J.M. and Stotzky, G. (eds.), Soil Biochemistry (Vol. 6), Marcel Dekker, New York: Marcel Dekker Inc.

Nannipieri P., Kandeler E., and Ruggiero P. 2002, Enzyme activities and microbiological and biochemical processes in soil; pp. 1-33 in: Burns R. G. and Dick R. P. (eds.), Enzymes in the. Environment: Activity, Ecology and Applications. New York: Marcel Dekker, Inc.

Onipchenko, V. G. 2011. The role of soil in formation and conservation of plant diversity; pp. 86-155 in: The role of soil in formation and conservation of biological diversity. Moscow: KMK Scientific Press.

Perel, T. S. 1979. Range and regularities in the distribution of the earthworms of the USSR. Moscow: Nauka Publishers. 272 pp.

Popova, O. V. 2016. [Uchebnoje posobije po Informatike.] Retrieved from [Informatika v shkole.] http://inf777.narod. ru/inf_posobie_popova/razdel_3.

Prokonova, T. V.2006. Mechanisms of adaptive responses in earthworms (Oligochaeta, Lumbricidae) to reduction of soil humidity in forest - steppe landscapes of the Central Ciscaucasus; pp. 63-65 in: Ecology problems of mountain territories. Moscow: KMK Scientific Press. 
Puzachenko, Yu.G. 2004. Mathematical methods in ecological and geographical research. Moscow: Publishing house ACADEMIA. 416 pp.

Rapoport, I. B. 2010. Seasonal activity of earthworms (Oligochaeta, Lumbricidae) from the belt of broad-leaved forests in the Kabardino-Balkar state high-mountain reserve and adjacent territories (Central Caucasus). Proceedings of the Samara Scientific Center of the Russian Academy of Sciences 12(1-5):1245-1248.

Shkhagapsoev, S. Kh. 2015. Vegetation cover of KabardinoBalkaria. Nalchik. Tetragraf. 350 pp.

Sokolov, V.E., and Tembotov, A. K. 1989. Vertebrates of the Caucasus. Mammals. Insectivores. Moscow: Nauka. $547 \mathrm{pp}$.

Speir, T. W., and Ross, D. J. 2002. Hydrolytic enzyme activities to assess soil degradation and recovery; pp. 407-431 in: Burns R. G. and Dick R. P. (eds.), Enzymes in the. Environment: Activity, Ecology and Applications. New York: Marcel Dekker, Inc.

Striganova, B.R. 1999. The structure and functions of soil populations; pp. 135-143 in: The structure-functional role of soil in biosphere. Moscow: Geos.
Striganova, B. R. 2005. Spatial variations of the functional structure of soil populations in the steppes of European Russia. Povolzhskiy Journal of Ecology (3):268-276.

Tembotova, F. A. and Tsepkova, N. L. 2009. On the problem of steppe ecosystem conservation in the Central Caucasus. Russian Journal of Ecology 40(1):65-67.

Tsepkova, N. L. 2006. Diversity of phytocenoses on plains of the Kabardino-Balkarian Republic; pp. 151-154 in: Environmental problems of mountain territories. Moscow: KMK Scientific Press,

Val'kov, V. F., Kolesnikov, S. I., and Kazeev, K. Sh. 2002. Soils of the South of Russia: Classification and Diagnostics. Rostov-on-Don: North Caucasus Scientific Center. 168 pp.

Val'kov, V. F., Eliseeva, N. V., Imgrut, I. I., Kazeev, K. Sh., and Kolesnikov, S. I. 2004. Reference book of the soil assessment. Maikop: GURIPP "Adigeya”. 236 pp.

Visotskiy, G.N. 1962. Earthworms: selected works; pp. 19-28 in: Vol. Il. Moscow: Publishing House of the USSR Academy of Sciences.

Vsevolodova-Perel, T. S. 1997. Earthworms of Russia's fauna. Moscow: Nauka Publishers. 102 pp.

World reference base for soil resources. 2006. World soils resources reports. № 103. Rome: FAO. 145 pp. 